Abstracta Iranica Abstracta Iranica

Revue bibliographique pour le domaine irano-aryen

Volume 26 | 2005

Comptes rendus des publications de 2003

\title{
Altsyrien und Libanon. Geschichte, Wirtschaft und Kultur vom Neolithikum bis Nebukadnezar. Darmstadt, 2002, 286 p., 3 cartes et aucune ill.
}

\section{Astrid Nunn}

\section{(2) OpenEdition}

\section{Journals}

Édition électronique

URL : http://journals.openedition.org/abstractairanica/2961

ISSN : 1961-960X

Éditeur :

CNRS (UMR 7528 Mondes iraniens et indiens), Éditions de l'IFRI

Édition imprimée

Date de publication : 15 mai 2005

ISSN : 0240-8910

Référence électronique

Astrid Nunn, «Altsyrien und Libanon. Geschichte, Wirtschaft und Kultur vom Neolithikum bis

Nebukadnezar. Darmstadt, 2002, 286 p., 3 cartes et aucune ill. », Abstracta Iranica [En ligne], Volume

26 | 2005, document 57, mis en ligne le 08 décembre 2005, consulté le 25 septembre 2020. URL :

http://journals.openedition.org/abstractairanica/2961

Ce document a été généré automatiquement le 25 septembre 2020.

Tous droits réservés 


\title{
Altsyrien und Libanon. Geschichte, Wirtschaft und Kultur vom Neolithikum bis Nebukadnezar. Darmstadt, 2002, 286 p., 3 cartes et aucune ill.
}

\author{
Astrid Nunn
}

Peu avant la synthèse sur l'histoire de la Syrie de P. Akkermans et G. Schwarz (cf. c.r. $\mathrm{n}^{\circ}$ 83) paraissait celle de M. Heinz. Son approche est plus sociologique et économique qu'archéologique. L'histoire de la domination perse achéménide est brièvement évoquée en guise de conclusion.

\section{INDEX}

Thèmes : 3.0. Généralités

nompropre Achaemenid, Syrie, Syria, achéménides

\section{AUTEURS}

ASTRID NUNN

Université de Munich 